\title{
Perfluorocarbon liquid-assisted intraocular foreign body removal
}

\author{
Lim Hui Wen, Siow Suyi, Ling Kiet Phang
}

Department of Ophthalmology, Hospital Sultanah Aminah, Johor Bahru, Johor, Malaysia

\section{Abstract}

Traumatic ocular injury is an uncommon yet leading cause of monocular blindness among the working-age group. Retained intraocular foreign body (IOFB) are associated with $41 \%$ of open globe injuries. Pars plana vitrectomy is often required for posterior segment IOFB removal. Advances in vitreoretinal surgical techniques and instrumentation have resulted in better treatment outcomes with reduced ocular morbidity. We report a case of modified ILM forceps with perfluorocarbon liquid-assisted non-magnetic IOFB removal in a young man after a motor vehicle accident with zone one open globe injury and a large glass IOFB in the right eye. We describe the use of perfluoro-N-octane to slide the IOFB extramacularly and reorient the IOFB plane for stable and safe retrieval by ILM end-gripping forceps. The modified design of the ILM end-gripping forceps with adjunctive use of perfluorocarbon liquid in pars plana vitrectomy reduces slippage during IOFB extraction and prevents collateral iatrogenic retinal injury.

Keywords: intraocular foreign body, open globe injury, perfluorocarbon liquid, trauma

\section{Abstrak}

Kecederaan traumatik okular adalah penyebab kebutaan yang jarang berlaku, tetapi penyebab utama kebutaan dalam golongan pekerja. Bendasing di dalam bebola mata dikaitkan dengan $41 \%$ kecederaan mata terbuka. Pembedahan vitrektomi pars planar sering diperlukan untuk membuang bendasing dari bahagian belakang mata.

Correspondence: Dr. Ling Kiet Phang, Department of Ophthalmology, Hospital Sultanah Aminah. Jalan Persiaran Abu Bakar Sultan, 80100 Johor Bahru, Johor Malaysia.

E-mail: lingkietphang@hotmail.com 
Kemajuan teknik dan alatan pembedahan vitreoretinal telah menghasilkan rawatan yang lebih bagus dengan kadar penurunan morbiditi mata. Kami membentangkan satu kes berkenaan penggunaan ILM forceps dan cecair perfluorokarbon untuk menyinkirkan bendasing bukan magnetik dari bebola mata iaitu serpihan kaca, yang melibatkan seorang pemuda yang terbabit dalam kemalangan jalan raya dan megalami kecederaan mata terbuka zon satu. Kami menghuraikan penggunaan perfluoro-N-octane untuk mengalihkan bendasing dari makula dan mengorientasikan semula bendasing bagi memudahkan penekstrakan bendasing dengan lebih stabil dan selamat dari bebola mata dengan menggunakan ILM forceps. Fungsi ILM forceps yang diubahsuai dengan bahan tambahan, iaitu cecair perfluorokarbon semasa pembedahan vitrektomi pars plana, akan mengurangkan gelinciran bendasing semasa pengekstrakan, seterusnya mencegah kecederaan retina secara iatrogeik.

Kata kunci: bendasing di dalam bebola mata, cecair perfluorokarbon, kecederaan mata terbuka, trauma

\section{Introduction}

Open globe injuries are often associated with a retained intraocular foreign body (IOFB). IOFBs are seen in $18-41 \%$ of open globe injuries, with a majority of cases occurring in men younger than 40 years of age.$^{1-3}$ Ocular injuries with retained IOFB pose serious threats to vision due to mechanical damage to intraocular structures, introduction of infection, and chemical reaction of foreign body with resultant retinal toxicity. The momentum of the object at the time of impact will determine the location of the IOFB either in the anterior chamber, and/or crystalline lens, and/ or posterior chamber, and/or even orbit in case of perforating injury. Accurate localisation of the IOFB and determination of its composition during examination are mandatory for surgeons to decide on the surgical approach for IOFB extraction. ${ }^{2}$ Currently, pars plana vitrectomy and IOFB removal with magnet or forceps is widely practised by surgeons in removal of posterior segment IOFBs. ${ }^{1}$ However, this method presents some drawbacks. Non-metallic IOFBs preclude the use of magnetic intraocular probes or the Bronson rare earth magnet. Forceps use has resulted in collateral damage associated with iatrogenic injury and slippage of IOFB during extraction.

We describe the benefits of perfluoro-N-octane (PFO), a perfluorocarbon liquid (PFCL), in the removal of a non-magnetic IOFB from the macula and posterior segment. In this case report, we demonstrate that PFO can be a useful adjunct to pars plana vitrectomy by facilitating the removal of a glass IOFB from the posterior segment and protecting the macula from iatrogenic damage. 


\section{Case presentation}

A 21-year-old male presented to the emergency department after a motor vehicle accident with a zone one open globe injury in the right eye. His visual acuity was light perception in the right eye and $6 / 6$ in the left eye. The right eye was soft on palpation. Slit lamp examination of the right eye showed a superotemporal curvilinear corneal laceration with uveal prolapse. The lens was cataractous with anterior capsule breech. The fundus view was obscured secondary to traumatic cataract. The patient underwent a primary open globe repair and lens aspiration.

When reassessed postoperatively, dilated fundus examination revealed a glass IOFB in the posterior segment with inferior retinal detachment and vitreous haemorrhage. The patient was referred to a vitreoretinal surgeon for IOFB removal. He underwent 23-gauge pars plana vitrectomy (Constellation ${ }^{\circledR}$; Alcon, Fort Worth, TX, USA). Intraoperatively, there was a large glass foreign body located in the posterior pole. After core vitrectomy, IOFB removal was attempted to no avail using a modified 23-gauge-ILM forceps (Grieshaber Revolution ${ }^{\circledR}$ DSP ILM Forceps; Alcon). The forceps was unable to grasp the glass IOFB securely given its orientation, large size, and smooth, slippery edges. One $\mathrm{mL}$ of PFO was then injected over the macula, displacing the IOFB extramacularly in order to protect the macula during removal. The glass piece was reoriented to incline against the PFO bubble using a vitrectomy cutter on aspiration. Repositioning of the glass piece enabled a stable forceps grip during removal. The IOFB was successfully removed from the anterior chamber via previously initiated corneal paracentesis wound with the modified ILM forceps forceps (Fig. 1). Ultimately, secondary implantation of a scleral-fixated intraocular lens was performed. At the 1-year postoperative follow-up, the patient had best-corrected visual acuity of $6 / 12$ in the right eye in the context of corneal scarring. Video 1 demonstrates the IOFB removal technique.
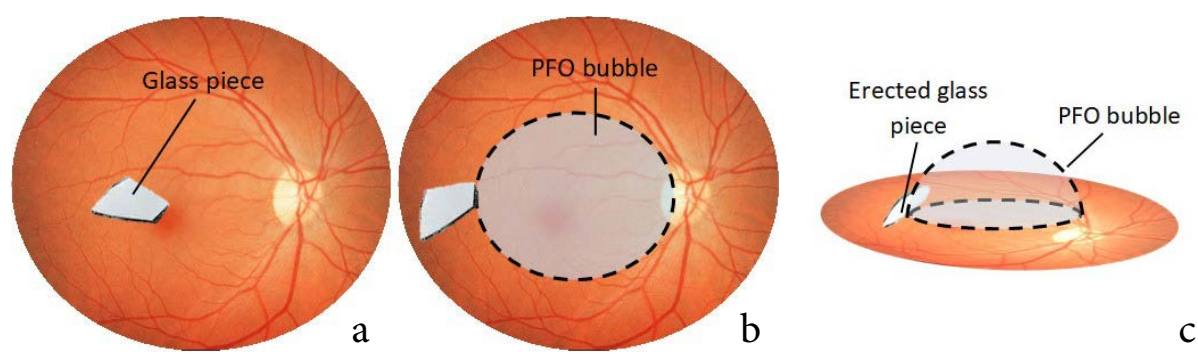

Fig 1. Schematic illustration of perfluorocarbon liquid-assisted intraocular foreign body removal. (a) Large piece of glass in the macula. (b) One $\mathrm{ml}$ of perfluoro- $\mathrm{N}$-octane (PFO) (as outlined by black dashed line) displaced the glass extramacularly. (c) The foreign body was reoriented vertically against the PFO bubble (as outlined by black dashed line) to facilitate forceps grip and foreign body removal. 


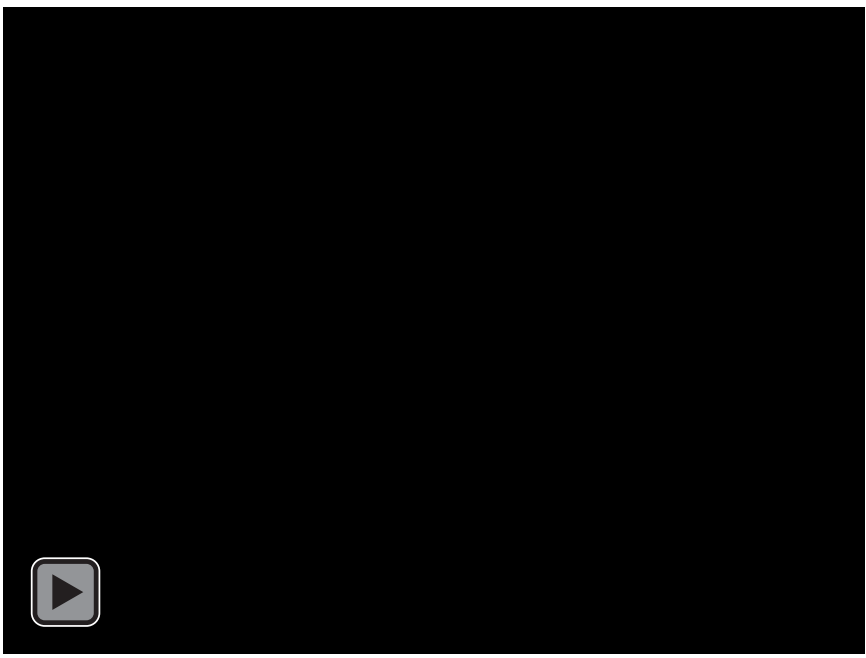

Video 1. This video demonstrates the use of perfluoro-N-octane (PFO), a perfluorocarbon liquid, in the removal of a large glass piece from the macula and posterior segment. PFO was injected to displace the foreign body extramacularly. The plane of the glass piece was reoriented to facilitate its removal using a modified ILM forceps. The glass piece was then removed from the anterior chamber using the modified ILM forceps. Note the secure grip of the glass piece by the ILM forceps despite its large size and smooth, slippery edges.

\section{Discussion}

Ocular trauma is the leading cause of monocular blindness, especially in the working-age population. Traumatic mechanical eye injury can be classified as either open globe or closed globe injury. IOFBs are associated with penetrating or open globe ocular trauma cases. The surgical approach and timing is case-dependent and must take into account the location, size, shape, IOFB composition, and presence of other associated injuries. The general principles of surgery are: timely closure of entry wound, IOFB removal, and prevention/treatment of endophthalmitis. ${ }^{4}$ Advances in vitreoretinal surgical techniques and instrumentation have allowed greater success in treating ocular injuries with retained IOFBs, thereby improving visual outcomes. ${ }^{1}$

This report presents a case of successful extraction of retained posterior segment glass IOFB in a young man after motor vehicle accident with good postoperative visual outcome. Posterior segment IOFBs pose challenges in treatment and tend to have worse visual prognosis, as they are commonly associated with vitreous haemorrhage, retinal tears, retinal detachment or dialysis, choroidal detachment, sclopetaria, etc. Profound visual loss that ensues from iatrogenic retinal injury is also common, as the IOFB may inadvertently fall posteriorly, 
striking the optic nerve or fovea, during surgical extraction. ${ }^{2,4}$ Thus, successful IOFB removal without collateral damage is an important indicator for recovery and visual prognosis.

IOFB removal from the posterior segment of the eye is challenging. Specific instrumentation is required to remove the IOFB depending on its size and magnetic nature. Small metallic IOFBs can be removed using intraocular rare earth magnets, but manoeuvring metallic IOFBs larger than $3 \mathrm{~mm}$ and non-metallic IOFBs such as stones or large glass fragments require specialised grasping forceps for removal. Various authors have described a snare or loop design made of thick sutures and nitinol loops that can hold irregular IOFBs. Snare design devices are not suitable for large spherical IOFBs because they are prone to repeated slippage of IOFB, leading to inadvertent iatrogenic retinal trauma. The use of different types of forceps have also been described by other surgeons in IOFB retrieval. Hickingbotham et al. have described a diamond-coated forceps to hold the IOFB in the vitreous cavity. However, the opening of the prongs is not wide enough to hold large IOFBs and the two prongs make removal of spherical IOFBs challenging. ${ }^{3}$ Liang et al. discussed the use of a microalligator forceps for removal of large IOFBs. The potential drawbacks of this instrument are the very large sclerotomy wound required to introduce the forceps and the potential crushing force of the forceps, which may splinter the IOFB. ${ }^{5}$ Acar has described a basket-shaped design of IOFB forceps made from nitinol. This basket is wide enough to extract large IOFBs, but its manipulation is technically difficult. ${ }^{6}$ The novel design IOFB forceps "the claw" (Epsilon, Chino, CA, USA) by Bapaye, consisting of four retractable prongs made of nitinol wire, offers a very secure grip without crushing the IOFB, thereby reducing the risk of IOFB slippage and iatrogenic retinal trauma. ${ }^{7}$

Liquid materials such as silicone oil, PFCLs, and viscoelastic liquids have been developed as adjunctive agents to facilitate vitreoretinal surge..$^{8-10}$ In the present study, we reported the use of PFO to realign the IOFB into the vertical plane and enable a stable hold of the object with the forceps, thus protecting the macula from secondary intraoperative retinal injury. Many studies have reported the application of PFCLs to protect the macula and to float IOFBs that are less dense than PFCLs into the vitreous body, but so far none have reported the role of PFCLs in reorienting an IOFB to facilitate a stable IOFB forceps grip for successful removal. ${ }^{11,12}$

PFCLs are low viscosity, low surface tension (14-16), optically clear compounds with refractive indices of $1.27-1.33$ but high specific gravity (1.76-2.3), nearly twice that of water. ${ }^{8,9,13}$ These properties make PFCLs a useful adjunct intraoperatively. PFCLs do not cause optical aberrations to surgeons because of their almost-similar-to-water-refractive index. The high specific gravity of PFCLs enables flattening of detached retinas and positioning of the foreign body away from the retina and into the vitreous body. The cohesiveness and low viscosity of PFCLs allow easy introduction and complete removal of the liquid intraoperatively. In this report, 
the IOFB was a glass piece with a greater specific gravity (2.0-2.5) than PFO; however, PFO could still be used to displace and reorient the IOFB extramacularly. This scenario is possible; a study evaluated and showed that PFCLs may be used to manipulate IOFBs with specific gravities higher than PFCLs after taking into account factors such as the PFCL's surface tension and buoyancy, in addition to the relative specific gravity of the IOFB to the PFCL. ${ }^{14}$

The special forceps for IOFB removal discussed above are not readily available to most of the ophthalmologists in our context. Thus, the modified ILM end-gripping forceps, which is designed for fine membrane grasping and maculorhexis, was used to remove the IOFB in this case. This instrument is inexpensive and readily available in our local context. In addition, we used PFO to erect the position of the IOFB, facilitate gripping, and minimize collateral retinal trauma, which is one of the determining factors in postoperative recovery and visual prognosis.

\section{Conclusion}

In this report, we describe the modified ILM end-gripping forceps with PFO-assisted removal of a large non-metallic IOFB. The intraoperative use of a modified ILM forceps and PFO facilitate IOFB removal by enabling reorientation of the IOFB for stable forceps grip in addition to its role in protecting the macula from iatrogenic retinal injury.

\section{Declarations}

Ethics approval and consent to participate

Not required.

\section{Consent for publication}

The patient provided informed consent for the publication of the clinical data and images contained in this case report.

\section{Competing interests}

None.

\section{Funding}

None.

\section{Acknowledgements}

None. 


\section{References}

1. Demircan N, Soylu M, Yagmur M, Akkaya H, Ozcan AA, Varinli I. Pars plana vitrectomy in ocular injury with intraocular foreign body. J Trauma. 2005;59(5):1216-1218.

2. Nicoară SD, Irimescu I, Călinici T, Cristian C. Intraocular foreign bodies extracted by pars plana vitrectomy: clinical characteristics, management, outcomes and prognostic factors. BMC Ophthalmol. 2015;15:151.

3. Hickingbotham D, Parel JM, Machemer R. Diamond-coated all-purpose foreign-body forceps. Am J Ophthalmol. 1981;91(2):267-268.

4. Ajay E. Kuriyan AVR. Update on the Management of Intraocular Foreign Bodies. Retinal Physician. 2017; 14(January 2017):[48-52 pp.].

5. Liang S, Wan G, Li X, Liu X, Zhu Y. Removal of a giant nonmagnetic intraocular foreign body using micro alligator forceps. Ophthalmic Surg Lasers Imaging Retina. 2014;45(3):228-230.

6. Acar N. A new design intraocular foreign body forceps. Retina. 2017;37(12):2378-2380.

7. Bapaye M, Shanmugam MP, Sundaram N. The claw: A novel intraocular foreign body removal forceps. Indian J Ophthalmol. 2018;66(12):1845-1848.

8. Georgalas I, Ladas I, Tservakis I, et al. Perfluorocarbon liquids in vitreoretinal surgery: a review of applications and toxicity. Cutan Ocul Toxicol. 2011;30(4):251-262.

9. Saxena S, Gopal L. Fluid vitreous substitutes in vitreo retinal surgery. Indian J Ophthalmol. 1996;44(4):191-206.

10. Park JH, Lee JH, Shin JP, Kim IT, Park DH. Intraocular foreign body removal by viscoelastic capture using DisCoVisc during 23-gauge microincision vitrectomy surgery. Retina. 2013;33(5):1070-1072.

11. Rejdak R, Choragiewicz T, Moneta-Wielgos J, et al. Intraoperative Macula Protection by Perfluorocarbon Liquid for the Metallic Intraocular Foreign Body Removal during 23-Gauge Vitrectomy. J Ophthalmol. 2017;2017:6232151.

12. Ung C, Lains I, Papakostas TD, Rahmani S, Miller JB. Perfluorocarbon liquid-assisted intraocular foreign body removal. Clin Ophthalmol. 2018;12:1099-1104.

13. Yu Q, Liu K, Su L, Xia X, Xu X. Perfluorocarbon Liquid: Its Application in Vitreoretinal Surgery and Related Ocular Inflammation. BioMed Res Int. 2014;2014:6.

14. Sudhalkar HA, Johnson MW. Perfluorocarbon liquid manipulation of high-density intraocular foreign bodies. Retina. 1998;18(5):460-465. 